\title{
The Human Resource crisis in the Zambian Health Sector - a discussion paper
}

\author{
Emmanuel Makasa \\ University of Alabama at Birmingham, \\ Birmingham, Alabama, USA
}

\begin{abstract}
Objectives: The human resource crisis facing the Zambian health sector has potential to derail existing health programs including millennium development goals. This paper will highlight the underpinning factors, analyze current interventions and propose alternative solutions to this crisis.
\end{abstract}

Design: The study was done through a review of articles and reports covering the topic.

Main outcomes/results: The human resource crisis has been recognized by the Zambian government, Zambian organizations and the international community as the greatest challenge that threatens the entire healthcare system. The situation is getting worse and solutions implemented thus far have neither been totally effective nor comprehensive in arresting, let alone reversing the trend.

Conclusion: The human resource crisis in Zambia has reached a disastrous stage with the health system at breaking point. Corrective measures have been started but these need to be strengthened and as comprehensive as can be. There is also need for innovation to consider other solutions that have not been tried before. This is important in order to safeguard Zambia's development and all the other investments that the country has made into its future through programs such as the fight against HIV/ AIDS. Although there is need for stronger international cooperation, the primary solutions can and must come from within Zambia.

\section{BACKGROUND}

The World Health Organization's current global estimates of countries facing critical shortages of medical staff stands at 57 with the greatest proportional shortfalls being in Sub-Sahara Africa. Africa, with a quarter of the world's disease burden has but only 3 percent of its health care workers. In Sub-Saharan Africa, there are 2.3 health workers per 1,000 people and in Zambia, a country with a population of approximately 12 million $^{1}$, the current doctor and nurse population ratios stands at 1 to 15,000 and 1 to 1,500 respectively. This is far lower than the WHO recommended doctor population ratio of one doctor to 5,000 and a nurse to a population ratio of 700 . About 1,198 Zambian nurses are working in seven European countries (equivalent to $5 \%$ of the total number of nurses in Zambia), and out of 1,200 doctors trained in Zambia since the late 1960s only 391 are practicing in the public sector today ${ }^{17}$. Health systems (in developing countries) are on the brink of collapse due to the lack of skilled personnel. In some countries, like Zambia, deaths from preventable diseases are rising and life expectancy is dropping. The consequences of this human resource crisis are grave as it leaves gaping holes in the healthcare systems of Zambia. Across the country, AIDS patients are often left unattended for days in rudimentary clinics staffed by a single overworked nurse and a few untrained orderlies ${ }^{3}$. Although the World Bank through a study have highlighted migration's potential benefits through remittances and the income multipliers they may create $^{25}$, such benefits cannot be relied upon to support the Zambian health sector in this time of crisis. There is therefore, an urgent need to address the human resource crisis in the health sector especially as programs such as antiretroviral treatment becomes more widely available. 


\section{UNDERPINNING FACTORS}

The following have been reported as the major causes of the human resource crisis in the Zambian public health sector:

1. "Brain-drain" due to immigration to the developed world outside Africa and to more developed countries within Africa such as South Africa. Within Zambia, there is also wide spread brain-drain to parallel programs run by international organizations and non-governmental organizations.

2. Zambia's inability to increase the output of trained health workers through increased intake or establishment of more schools to match the rising population and increasing disease burden. There is only one medical school in Zambia with an average output of fifty doctors per year.

3. Weak retention policies and programs that have failed to arrest the brain-drain that is primarily caused by the "push factors" of low salaries and poor working conditions.

4. The Zambian health sector has not been spared by the HIV/AIDS pandemic which has resulted in deaths of many health workers.

The Brain-Drain: Reasons advanced by health personnel that have immigrated outside the country are mostly economic - better working conditions with higher wages and that of a search for a better working environment in a well functioning health system. Other personal factors such as the need to live in a more developed country with better schools for children also play a role especially in the face of existing cultural and social beliefs of western countries having better life styles. Individual doctors for example, are understood to be striving for a better life elsewhere-some for themselves and for personal gain, but many so that they could better support their families who are left behind. Doctors and nurses also desire and need better training, which a poor country like Zambia cannot satisfy ${ }^{5}$.

Training: Zambia has a single medical school under the public funded University of Zambia that produces on average 50 doctors each year. Medical education for almost all students is attained under a non refundable government scholarship. Although there has been a push to increase output, this has not been possible due to limited space and other resources at the medical school. Neither the Zambian government nor the private sector has set up any other medical schools. A few private nursing schools have been established in the past two years but this is just the beginning and their benefits yet to be realized. These private schools have a very low intake too because most students and families cannot afford the tuition fees compared to the limited but already established government nursing school where education is almost free. Graduate training is also only offered at the University Teaching Hospital under the University of Zambia, school of medicine. This limits the number of possible graduates that could be mobilized as staff to set up new medical or nursing schools. Thus, the output of trained health workers has not matched the rising Zambian population and the increasing disease burden from illnesses such as HIV/AIDS, Malaria and Tuberculosis to mention but a few.

Retention: Medical education in Zambia is mostly free under the Bursaries Committee scholarships from the Ministry of Education. Under this public funded program, students have $90 \%$ of their tuition fees paid for, receive a monthly living allowance, and receive a utility inclusive free accommodation on campus besides other allowances for research and textbooks. This scholarship in non-refundable and there are no mechanisms of recovery of these public funds from the medical graduates making it easier for them to immigrate. It is very obvious that student loans in countries like the United States make it hard for medical graduates to leave the country, but as indicated, this is not the case in Zambia.

HIV/AIDS: HIV/AIDS affects the performance of health systems by increasing demand for services in both quantity and complexity and by reducing the supply of services by its impact on the numbers and performance of the health workforce ${ }^{24}$. These processes are associated with increased costs at a time when funding for health care is diminishing, particularly in a developing country like Zambia. The lack of trained human resources is one of the most significant challenges to scaling up the health sector's response to HIV/AIDS. The high prevalence of HIVrelated illness in Zambia has seriously overburdened 
the health care system at all levels, accentuating the burden on a thinly stretched workforce whose numbers are also diminishing due to HIV/AIDS

As can be seen from the underpinning factors outlined above, the solutions for the human resource crisis are primarily in the hands of Zambia and other regional governments although there are international efforts to arrest the trend.

\section{CURRENT INTERVENTIONS}

This human resource crisis is so devastating and threatens to collapse the health care system ${ }^{7}$ in Zambia, like other southern African countries. It threatens to reverse and derail any national health programs such as the fight against HIV/AIDS ${ }^{8}$, the antiretroviral program, and the fight against Malaria and tuberculosis. It can influence each of the millennium development goals either directly or indirectly ${ }^{9}$ and greatly reduces any possibility of attaining the millennium development goals. It is because of the above highlighted magnitude of impact of this crisis that it has attracted international and national attention and counter programs are already underway.

International Cooperation and Policy: WHO, has, in a report suggested that international aid to Africa should be used to boost doctors' salaries and bolster recruitment and training ${ }^{3}$. Countries like Britain have enacted new laws under the European Union to discourage immigration of health workers. The new laws stipulate that employers in Britain will only be granted work permits for foreign nurses if they can prove that no suitable British or European Union candidate can be found ${ }^{11}$. Within the SADC region, South Africa has banned the recruitment of its health workers from other Southern African countries ${ }^{12}$. At national level within Zambia a number of incentives have been tried to persuade doctors to remain in or return to Zambia through enhanced salaries, car loans, and housing allowances.

\section{Zambian Health Workers Retention Scheme (ZHWRS): To tackle problems of staff shortage and} maldistribution, in 2003 the Government of the Republic of Zambia in partnership with the Royal Netherlands Government embarked on a Pilot Zambian Health Workers Retention Scheme (ZHWRS) for health professionals. The scheme had as first objective to replace the Dutch doctors, working under the bilateral agreement between Zambia and the Netherlands ${ }^{19}$. The current objective after a review of this scheme is to decrease attrition rates of current critical service providers especially in rural areas. The scheme design is that it is an incentive program targeting key health worker cadres primarily in rural districts. The number of supporting partners has now increased and includes USAID, HSSP, EU, SIDA, DFID and CIDA ${ }^{13}$.

Table 1. Zambia Health workers Retention Scheme Incentive Packages (Source: HSSP)

\begin{tabular}{|c|c|c|c|c|c|}
\hline $\begin{array}{c}\text { Employee } \\
\text { Category }\end{array}$ & $\begin{array}{l}\text { Monthly } \\
\text { Stipend } \\
\text { (Hardship } \\
\text { Allowance) }\end{array}$ & $\begin{array}{c}\text { Housing } \\
\text { Rehabilitation }\end{array}$ & $\begin{array}{l}\text { Vehicle Loan } \\
\text { Available }\end{array}$ & Facility Incentives & $\begin{array}{c}\text { Duration of } \\
\text { Contract }\end{array}$ \\
\hline $\begin{array}{c}\text { Zambian } \\
\text { Medical } \\
\text { Consultants }\end{array}$ & $\$ 935.10$ & $\$ 3000$ & Yos & $\begin{array}{l}\text { Provision of modical } \\
\text { equipment at Provincial } \\
\text { Hospitals }\end{array}$ & $\begin{array}{c}3 \text { consecutive } \\
\text { years }\end{array}$ \\
\hline $\begin{array}{l}\text { All Modical } \\
\text { Officers }\end{array}$ & $\begin{array}{l}\mathrm{C}-\$ 579.33 \\
\mathrm{D}-\$ 685.10\end{array}$ & $\$ 3000$ & $\begin{array}{l}\text { Yos, after comploting } 6 \\
\text { months of contract }\end{array}$ & $\begin{array}{l}\text { Provision of modical } \\
\text { equipment at Hoalth } \\
\text { Centers and District } \\
\text { Hospitals }\end{array}$ & $\begin{array}{c}3 \text { consocutive } \\
\text { years }\end{array}$ \\
\hline $\begin{array}{l}\text { All Modical } \\
\text { Licentiates }\end{array}$ & $\begin{array}{l}C-\$ 371.70 \\
D-\$ 472.50\end{array}$ & $\$ 3000$ & $\begin{array}{l}\text { Yos, after comploting } 6 \\
\text { months of contract }\end{array}$ & $\begin{array}{l}\text { Provision of medical } \\
\text { equipment, improvement of } \\
\text { water reticulation systems }\end{array}$ & $\begin{array}{c}3 \text { consecutive } \\
\text { years }\end{array}$ \\
\hline $\begin{array}{c}\text { Zambian Nurse } \\
\text { Tutors }\end{array}$ & $\begin{array}{c}\mathrm{A}=250 \\
\mathrm{~B}=371.70 \\
\mathrm{C}=472.50\end{array}$ & $\begin{array}{l}\text { Applicable at } \\
\text { select facilities }\end{array}$ & Not Applicable & $\begin{array}{l}\text { Rehabilitation of schools, } \\
\text { provision of medical } \\
\text { equipment, upgrading staff } \\
\text { accommodation }\end{array}$ & $\begin{array}{c}3 \text { consecutive } \\
\text { years }\end{array}$ \\
\hline $\begin{array}{c}\text { Zambian } \\
\text { Clinical Officers } \\
\text { Nurses } \\
\text { EHTs }\end{array}$ & $\$ 200$ & $\begin{array}{l}\text { Rehabilitation of } \\
\text { clinic building } \\
\text { and staff houses }\end{array}$ & $\begin{array}{l}\text { Provision of one motor } \\
\text { bike per Health Center }\end{array}$ & $\begin{array}{l}\text { Provision of solar panels, } \\
\text { medical equipment, water } \\
\text { reticulation systems }\end{array}$ & $\begin{array}{c}3 \text { consecutive } \\
\text { years }\end{array}$ \\
\hline
\end{tabular}


The Task Shifting Project: This is WHO/PEPFAR collaboration with Zambia among other countries ${ }^{20}$. The goal of the project is to increase the number and skills of the health care workforce in a way that could transform the response to the HIV epidemic by improving the overall access to and quality of HIV?AIDS prevention, care and treatment services. Under this initiative, tasks normally preformed by doctors, nurses and pharmacists would be reallocated to other health workers.

\section{REVIEW OF EFFECTIVENESS OF CURRENT INTERVENTIONS}

Like many other international efforts, good programs are designed but there is always something wrong with the implementation process. The WHO advice to channel aid money towards the remunerations and recruitment of health cadres does not go far as politics of the Zambian government and the labor movement continue to override. The government is reluctant to increase salaries of health workers by a considerable meaning amount citing opposition from the labor movement that would want this done across the board to include other sectors that they represent and have successfully used the courts of law to block the delinking of health works from the civil service union. Many in countries such as the UK are opposed to the law banning the recruitment of health workers from the developing world saying it is unfair to turn against these professional that have served the NHS for a long time now and also cite the benefits of the large sums of moneys that these professional send back home and thus helping their national economies ${ }^{5}$. In South Africa for example, the directive to ban the employment of health workers only affects the public sector and so the private sector continues to employ them.

Intervention measures implemented at national level are still in their infancy and relatively ineffective. As mentioned above, no meaningful increment in salaries has taken place while health workers remain under the civil service union. The World Bank and IMF too through their heavily Indebted Poor Countries (HIPC) initiative in November 2000, Zambia's public sector wages were not to exceed $8 \%$ of the Gross Domestic Product (GDP) in order for the country to qualify for a relief of about half of its $\$ 6.8$ billion debt. To meet this, from the year 2000 to 2005 there was no salary increment of any civil servant despite rising price levels. Housing allowances were reduced to unacceptable levels ${ }^{16}$, No new civil servants were employed despite a shortage of health workers ${ }^{14}$. A study done in Lusaka reviewed that that nurses receive an average monthly remuneration of $\mathrm{K} 1.1 \mathrm{~m}$ (US\$229). Also clinical officers receive a monthly salary of K $1.1 \mathrm{~m}$ (US\$ 299). Their remuneration consists of the salary and regular uniform and night duty allowance paid as composite every month. In comparison with other governmental staff like pharmacy technologists, environmental health technologists and radiographers with similar duration of training, the salaries can be seen to be reasonable. Nevertheless, they are low when compared with the monthly food basket requirements estimated to be in the range of $\mathrm{K} 1.4 \mathrm{~m}$ (US\$ 350 ) for a family of six, and they do not at all allow meeting the additional costs of decent housing, transport and other basic services like water and electricity. These low salaries are an important factor driving nurses and clinical officers to a "breaking point" and the decision to migrate from the governmental sector and search for new jobs that could pay them a better living wage $^{17}$. The car loan scheme is also bogged down with lots of problems as it does not cover all health workers let alone all doctors besides the fact that second hand Japanese vehicles are what are given out at a price higher than the competitive market. When it comes to getting doctors to rural areas, however, there may be reason for optimism. Under a "rural retention" program supported by donor countries, doctors are given monthly allowances, a one-time payment to upgrade their housing, a car loan after 6 months of service, and a number of work-related incentives-all in return for 3 years of service at a rural facility. The initiative has seen some success and is being expanded to include nurses and other medical professionals ${ }^{15}$.

The initiative to re-allocate tasks normally done by doctors and nurses to other health workers is a good move to ensure that HIV/AIDS programs are not derailed. However, they should not be seen as long term measures especially that they only cover one disease entity.

\section{PROPOSED ALTERNATIVE INTERVENTIONS}

Although international support is welcome, the solutions to the human resource crisis that Zambia is faced with will primarily need local solutions. 
1. Retention of Health workers: The human resource crisis must be declared a national disaster so that government can have more powers to address the situation without interference from labor movements and organizations such as the IMF. The initial goal would be to retain health workers that are already working in the public sector of the country and avoid them leaving. The government will then be able to delink health workers from the Civil Servants Union of Zambia and adequately address their inadequate salaries that have been cited as crucially important. According to the recent World Health Report of 2006, the driving forces for migration are manifold and include low remunerations, poor working conditions, absence of career development schemes, civil strife and political instability, fear to contract diseases such as HIV and country policies that encourage labor export like in the Philippines ${ }^{17}$. Car loans, rural hardship allowances and education allowances for children were extended to all Zambian doctors working in rural districts. Progression training was spelt out for doctors to encourage new graduate doctors to work in smaller districts for two or three years after internship. Thereafter they are eligible for government scholarship study. These have motivated the doctors to remain in the public health sector in recent times and there are many other factors that still remain attractive for doctors to remain in Zambia ${ }^{23}$. However, the selective incentives contained in the retention scheme have not yet been extended to the nurses and clinical officers to date and these cadres continue to migrate ${ }^{17}$. Thus, to retain these health cadres, there is urgent need to extend most if not all incentives given to rural practicing doctors under the rural retention scheme. Other non monetary incentives should also be considered such as land that could be advanced to health cadres which they would have to pay for over a long period of time (say 25 years). Government should also find a way of partnering with the private sector such as banks to give housing mortgages with good conditions to the health workers to keep them in the country for a longer time while they repay.

2. Increase output and return: There is also an urgent need for massive investment into new schools that could increase the output of the needed health workers. The commission for Africa in its report of March, 2005, called for an extra one million health workers to be trained in Africa by $2015^{22}$. Local staff could be recruited from those graduating from the Master of Medicine (M.Med) program of the University of Zambia to set up medical schools at tertiary level hospitals such as Kitwe Central Hospital and Ndola Central Hospital. Doctors that are outside the country and who have had specialist training could also be encouraged to return and teach at the new schools with good conditions of service.

3. Working conditions: Working conditions are important for motivating health workers to perform their tasks. Satisfactory working conditions comprise a clean and safe environment, innovative management, availability of medical equipment and supplies. Besides, it is essential that the staff is not overwhelmed with work ${ }^{17}$. These working conditions have been a cause of industrial strife -was one of the issues that resulted in a nine month long doctors' strike in the year $1999^{21}$. Health workers in Zambia are demotivated by the commonly run down health facilities coupled with the heavy work load from the increased disease burden. The political leadership is aware of this fact and continues to spend huge sums of money on medical services abroad ${ }^{22}-$ money which could be rechanneled to improving these facilities to the benefit of all citizens.

Bonding: The Zambian government should consider giving favorable and competitive student loans to students at entry into health training institutions on condition that the students would be legally bonded to work with Zambia until they repay back. This should not only be seen as a way of solving the health sector human resource crisis but it is a way of creating the much needed jobs in a country with very high unemployment rates. Licensing and regulatory bodies such as the Medical Council of Zambia and General Nursing Council of Zambia should consider only issuing graduate trainees full registration status to practice after the bonding agreement with government is served in the Public Health Sector ${ }^{17}$. Medical graduates in countries like the United States usually have huge student loans that take time to repay and in the Zambian setting, these graduates would have settled into society (married with children) and may be reluctant to leave at this stage because of family responsibilities. 


\section{CONCLUSION}

The human resource crisis in Zambia has reached a disastrous stage with the health system at breaking point. In the face of increased population and increased disease burden, there are very few health workers in the public sector who are overwhelmed, demotivated and underpaid. Corrective measures have been started but these need to be strengthened and as comprehensive as can be. There is also need for innovation to consider other solutions that might seem radical or that have not been tried before. This is important in order to safeguard Zambia's development and all the other investments that the country has made into its future through programs such as the fight against HIV/AIDS. The private sector in Zambia must be encouraged to take up an active role in solving this crisis as it also threatens their investments through a weak and unhealthy human resource that will not be productive. Although there is need for stronger international cooperation, the primary solutions can and must come from within Zambia. The argument that Zambia will benefit from migration's potential benefits through remittances and the income multipliers they may create, though true, is out of position and thus cannot be relied on.

\section{REFERENCES:}

1. CENTRAL STATISTICAL OFFICE ZAMBIA (2000). Main Zambia Census Report, Vol. 10. Lusaka: Zambia.

2. Development Gateway. Capacity development for MDGs. Rising to the challenges: the millennium development goals for health. 12 November 2004. topics.developmentgateway.org/mdg/rc/ ItemDetail.do 1024486 .

3. K Chandran, T E Lyn. Medical brain drain plagues developing countries. Reuters (2008). news.yahoo.com/s/nm/20081001/wl_nm/ us_braindrain_2 - 71k

4. Humanitarian news and analysis: UN Office for the Coordination of Humanitarian Affairs. SOUTHERN AFRICA: Band aid for medical brain drain (2008). http://www.irinnews.org/ report.aspx ?reportid $=60374$

5. B Twisselmann. Africa's medical brain drain Summary of responses to recent editorial on stopping Africa's brain drain. BMJ 2005;331:780-781 (1 October), doi:10.1136/bmj.331.7519.780-c. http:// www.bmj.com/cgi/content/full/331/7519/780-c

6. WHO (2005). Summary Country Profile for HIV/AIDS Treatment- Zambia. www.who.int/ hiv/HIVCP_ZMB.pdf

7. B M Kuehn, Global Shortage of Health Workers, Brain Drain Stress Developing Countries JAMA. 2007;298:1853-1855.

8. E. A. Friedman, Responses to brain drain of African health professionals to the United States and other developed countries; International Conference on AIDS (15th : 2004 : Bangkok, Thailand).

9. International Organization for Migration (IOM), 2005: The Millennium Development Goals and Migration.

10. N. G. Sarava, J.F. Miranda. Plumbing the brain drain, Bulletin of the World Health Organization (WHO) 2004;82:608-616.

11. BBC, 2006: Foreign nurses clampdown by NHS. http://news.bbc.co.uk/2/hi/health/5140648.stm

12. C. Zondagh, Public Service International, South Africa: Ban on recruitment from the SADC countries. http://www.worldpsi.org Template.cfm?Section $=$ Home $\&$ CONTENTID= 10269\&TEMPLATE=/ContentManagement/ ContentDisplay.cfm

13. H. F. Mwale, S. Smith, Human Resources Retention Scheme: Qualitative and Quantitative Experience from Zambia. Health Services and System Program (HSSP). www.who.int/ workforcealliance/forum/presentations/ Hilary_Francis.pdf

14. "ZAMBIA: The IMF or the people". New African. . FindArticles.com. 01 Nov. 2008. http:/ /findarticles.com/p/articles/mi_qa5391/ is_200405/ai_n21355168

15. J. J. Schatz, World Report: Zambia's healthworker crisis. The Lancet, Volume 371, Issue 9613, 23 February 2008-29 February 2008, Pages 638-639

16. Zambia: Doctors' Strike Troubling, Times of Zambia (Ndola), Editorial 14 ${ }^{\text {th }}$ August 2008. http://allafrica.com/stories/200808140521.html

17. D. Lusale, Why do Zambian health workers migrate abroad? The Brain Drain of Zambia health workers. Medicus Mundi Switzerland No.104, May 2007. http:// 
www.medicusmundi.ch/mms/services/bulletin/ bulletin104_2007/chapter0705168999/ bulletinarticle0705162432.html

19. Koot J, Martineau T, Zambian Health Workers Retention Scheme (ZHWRS) 2003-2004, HRHGlobal Resource Center, 2005. http:// www.hrhresourcecenter.org/node/868

20. WHO-Global Recommendations \& Guidelines, Task Shifting: Rational redistribution of tasks among health workforce teams, 2007.

21. Ahmad k. 200 junior doctors sacked in Zambia, Lancet.200 Jul 29;356(9227):410. http:// www.ncbi.nlm.nih.gov/pubmed/10972385

22. BBC (2005): Plugging the brain drain. http:// news.bbc.co.uk/2/hi/africa/4339947.stm
23. Makasa E. Africa's medical brain drain: Why I want to stay in Africa, BMJ 2005;331:780 (1 October), doi:10.1136/bmj.331.7519.780-b, http:// www.bmj.com/cgi/content/full/331/7519/780-b

24. L. Tawfik, S. N. Kinoti, The Impact of HIV/ AIDS on Health Systems and the Health Workforce in Sub-Saharan Africa, Usaid, Bureau for Africa, Office of Sustainable Development. June 2003

25. World Bank Report (2005): International Migration, Remittances and the Brain Drain. Determinants of Migration, Destination, and Sector choice: Disentangling Individual, Household, and Community effects. http:// go.worldbank.org/HONV2TILD0 